\title{
Age Differences of Human Sphenoid Sinus Dimensions: a Comparative Study by Gross Anatomical Dissection and CT Scan Imaging
}

Mohammad Ahmad ABDALLA ${ }^{\top}$

\begin{abstract}
Introduction: The sphenoid sinus is a central skull cavity situated inside the sphenoid bone as a twin structure, separated by a complete bony septum. The aim of the study to measure the length, width, and height of human sphenoid sinus through dissection compared to CT scan images in different age groups of both genders. Methods: A prospective study of 360 human bodies including 110 dissected cadavers and 250 individuals with CT scan images during a period from January 2019 to February 2020. Results: In male cadavers, the mean value of length was (24.8 \pm 4.2$)$ and $(23.6 \pm 3.8) \mathrm{mm}$ for right and left sides, while for females was $(24.5 \pm 3.7)$ and $(25.3 \pm 4.1) \mathrm{mm}$. Whereas, for CT cases were (25.4 \pm 3.1$),(27.2 \pm 4.1),(21.3 \pm 4.2)$, and $(24.4 \pm 3.8) \mathrm{mm}$ respectively. Otherwise, the width was (15.8 \pm 3.2$)$ and $(19.2 \pm 4.5) \mathrm{mm}$ for right and left sides in male cadavers; but for females was (18.2 \pm 3.8$)$ and

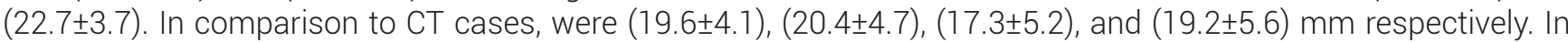
male cadavers, the height was (21.4 \pm 3.1$)$ and $(26.8 \pm 2.8) \mathrm{mm}$ for right and left sides, while for females was (13.8 \pm 3.3$)$ and $(19.6 \pm 3.1) \mathrm{mm}$. Whereas, for CT cases were (16.7 \pm 2.5$),(18.2 \pm 2.7),(14.6 \pm 2.9)$, and $(15.8 \pm 3.3) \mathrm{mm}$ respectively. Conclusion: Findings of both methods yield accurate anatomic sinus views, which may determine the age, gender, and race of alive or dead individuals.
\end{abstract}

Keywords: Computed Tomography (CT), gross anatomy, dissection, dimensions, sphenoid paranasal sinus.

1 Department of Human Anatomy, College of Medicine, Tikrit University, Tikrit, Iraq
Corresponding author:

Mohammad Ahmad ABDALLA, Department of Human Anatomy,

College of Medicine, Tikrit University, Yarmook Street, Box 45,

Tikrit 28001, Iraq.

E-mail: dr.mohammad68@tu.edu.iq 


\section{INTRODUCTION}

The sphenoid paranasal sinus is a twin structure situated within sphenoid bone. A complete septum lied in the mid-sagittal plane separated the paired cavity sinus ${ }^{1}$. This usually causes asymmetrical shape and size of the sinus, but a recognizable septal deviation is relatively rare $^{2}$.

This sinus is characterized anteriorly by an incomplete bony margin that separating its mucosa from posterior ethmoidal sinus and nasal mucosa, but posteriorly, a thick bony margin separating it from the basilar artery and pons. In addition, when the sphenoid paranasal sinus becomes bigger in size, it can be extended above the contents of pterygopalatine fossa or even can be situated directly behind the maxillary sinus ${ }^{3,4}$.

Computed Tomography (CT) is an entirely nondestructive technical procedure used to visualize the internal features of many opaque solid materials and to obtain three-dimensional geometrical digital data ${ }^{5}$. Spiral CT is regarded as a quick scanning procedure that permits improved contrast boosting and decreases motion artifacts; therefore, it enables the radiologists to visualize structures quickly and manipulates volumetric information in three-dimensional reconstructed images $(3 \mathrm{D}-\mathrm{CT})^{6,7}$.

On the other side, 3D-CT scanning considers as a procedure that is more accurate to determine the dimensions than scanning obtained directly from 2DCT image reconstruction ${ }^{8}$. In many clinical cases, the linear craniofacial measurement was proven more accurate when measured by $3 \mathrm{D}-\mathrm{CT}$ imaging compared to a corresponding physical measurement $\mathrm{t}^{9,10}$.

This study aims to determine the measurements of the anteroposterior length, width, and height of the human sphenoid paranasal sinus done by gross anatomical dissection and compare them to measurements done by axial, sagittal, and coronal CT scan images in different age groups of both genders.

\section{MATERIALS AND METHODS}

A randomized sample of 360 human bodies was chosen for this study. Including 110 cadavers who were dissected at Baghdad Forensic Medicine Institute and the Tikrit Forensic Medicine Unit, while another 250 cases were apparently healthy normal individuals who attending the Radiology Section of both Baghdad Medical City and Tikrit Teaching Hospitals, as arranged in Table
(1). This prospective study was carried out during the period from January 2019 to February 2020.

Table 1. Distribution of participating human cadavers and $\mathrm{CT}$ living individuals according to age and gender.

\begin{tabular}{|c|c|c|c|c|c|c|c|}
\hline & & \multicolumn{3}{|c|}{$\begin{array}{c}\text { Human Cadaver } \\
\text { Cases }\end{array}$} & \multicolumn{3}{c|}{ CT Cases } \\
\hline Group & Age & $\begin{array}{c}\text { Male } \\
\text { No. }\end{array}$ & $\begin{array}{c}\text { Female } \\
\text { No. }\end{array}$ & $\begin{array}{c}\text { Total } \\
\text { No. }\end{array}$ & $\begin{array}{c}\text { Male } \\
\text { No. }\end{array}$ & $\begin{array}{c}\text { Female } \\
\text { No. }\end{array}$ & $\begin{array}{c}\text { Total } \\
\text { No. }\end{array}$ \\
\hline Group 1 & $20-29$ years & 16 & 14 & 30 & 35 & 30 & 65 \\
\hline Group 2 & $30-39$ years & 14 & 11 & 25 & 32 & 31 & 63 \\
\hline Group 3 & $40-49$ years & 13 & 12 & 25 & 30 & 28 & 58 \\
\hline Group 4 & $50-59$ years & 15 & 15 & 30 & 33 & 31 & 64 \\
\hline \multicolumn{2}{|r|}{ Total } & $\mathbf{5 8}$ & $\mathbf{5 2}$ & $\mathbf{1 1 0}$ & $\mathbf{1 3 0}$ & $\mathbf{1 2 0}$ & $\mathbf{2 5 0}$ \\
\hline
\end{tabular}

The current study included the human cadavers for those individuals who dissected at forensic medicine for a death cause, which not associated with head or respiratory system; therefore, any died case due to maxillofacial injury, head trauma, brain tumor, or any other correlated death cause was excluded from the study. While the CT cases included those individuals who had complained of headache and were referred to the radiology section to have CT scans for brain and paranasal sinuses in which no pathological findings were detected in these sinuses. On the other hand, patients with surgical interference history, trauma, or any pathological lesion at the skull or maxillofacial area were excluded from the present study.

Cadavers of 110 individuals were dissected by specific gross anatomical dissection for the head region. The fresh human cadaver was precisely and carefully dissected in order to reach the various regions of sphenoid paranasal sinus. The cadaver head was firmly fixed into a particular woodblock and anchored by multiple screws, so that precise sagittal sectioning may be obtained and demonstrating these sinuses. This very fine and precise sagittal sectioning was prepared, using either fine manual saws or orthopedic band saws, which have very fine teeth that producing very thin sheets during dissection process. Using an $8400 \mathrm{~K}$ digital optical micrometer and digital vernier caliper with a laser sensor, the three anatomical dimensions of sphenoid paranasal sinus were identified and recorded.

The imaging protocols used in the current study including 3 to $5 \mathrm{~mm}$ slice thickness, $140 \mathrm{kVp}, 94$ mAs, 2000 window width, 400 window level, and 
35-45 second scan time. Utilizing 3D program of the CT Siemens workstation, which characterized by a resolution maximum $1280 \times 1042$ screen formats and a picture size $360 \times 288 \mathrm{~mm}$. The workstation permitted synchronous viewing of a particular reference point at three view sections (the axial, sagittal and coronal); then capture these images in JPEG format and downloaded them on CD for transfer of its data. Specimens were digitally photographed using a Panasonic HDD-H80 camera.

Some criteria depend upon it in order to produce accurate measurements for the sinus dimensions. Including the length of each sphenoid sinus was measured by measuring the longest anteroposterior margin of that sinus, so it was measured from the reformatted axial section, which was in parallel with hard palate. While the width of sinus was taken from lateral wall outermost point of that sinus directly throughout it to medial wall of the same sinus, so it was measured from the reformatted axial section, which was in parallel with hard palate. On the other side, the height of this sinus was taken from superior wall uppermost point of the sinus directly throughout it to inferior wall lowermost point of the same sinus, so it was measured from the reformatted coronal section which was vertical on hard palate ${ }^{11-15}$.

Information was transferred to a database computer and inputted by utilizing SPSS version 26. The frequency distribution of selected sample variables was carried out first. Then the quantitative variables outcome measurements were put in normal distribution curve and tabulated with mean, standard deviation and statistical parametric tests for significance were employed. T- test of independent samples and ANOVA test was utilized for evaluation of any statistical significance and p-value $\leq 0.05$ level was regarded as statistically significant.

\section{RESULTS}

\section{Sphenoid sinus length measured in dissected human cadavers}

The mean value of right sphenoid sinus length for males was $(24.8 \pm 4.2) \mathrm{mm}$ and of the left was $(23.6 \pm 3.8) \mathrm{mm}$. whereas, the mean value for right sphenoid sinus length in females was $(24.5 \pm 3.7) \mathrm{mm}$ and for the left sinus was $(25.3 \pm 4.1) \mathrm{mm}$. No significant side difference was revealed for both genders ( $p>0.05)$, as demonstrated in Table 2.
In the age grouping of this study, the maximum length of the sphenoid sinus for males presented in group 2 on right side with $(26.7 \pm 3.8) \mathrm{mm}$, while its minimum length belonged to group 3 on left side with $(21.4 \pm 3.8) \mathrm{mm}$. On contrary, for females, the maximum sinus length presented in group 3 on left side with $(27.6 \pm 4.1) \mathrm{mm}$. While the minimum sinus length presented in group 4 on left side with $(22.3 \pm 4.3) \mathrm{mm}$. ANOVA test revealed a statistically significant difference in both sides of males and only for left side in females ( $\mathrm{p} \leq 0.05)$, when it was used for all age groups, as shown in Table 3.

\section{Sphenoid sinus length measured by CT}

In males, the mean for right sphenoid sinus length was $(25.4 \pm 3.1) \mathrm{mm}$, and the mean of the left sphenoid sinus length was $(27.2 \pm 4.1) \mathrm{mm}$, but in females, the mean for the right sphenoid sinus length was $(21.3 \pm 4.2) \mathrm{mm}$, and of the left sinus was $(24.4 \pm 3.8) \mathrm{mm}$. The mean values of right side were statistically significant between both genders $(p \leq 0.05)$, while the left side reported no significant difference ( $p>0.05)$, as summarized in Table 4.

In age groups, the maximum length of sphenoid sinus for males presented in group 1 on left side with $(29.1 \pm 4.2) \mathrm{mmm}$. Whereas, it is minimum length belonged to group 3 on right side with $(23.6 \pm 2.9) \mathrm{mm}$. On contrary, for females, the maximum sinus length presented in group 3 on left side with $(26.2 \pm 4.2) \mathrm{mm}$. Furthermore, the minimum length belonged to group 3 on right side with $(18.6 \pm 3.8) \mathrm{mm}$. Using ANOVA test; there was a significant difference $(\mathrm{p} \leq 0.05)$ in recorded mean values for both sides among the four age groups in both genders, as shown in Table 5 .

\section{Sphenoid sinus width measured in dissected human cadavers}

For males, the mean right sphenoid sinus width was $(15.8 \pm 3.2) \mathrm{mm}$, and $(19.2 \pm 4.5) \mathrm{mm}$ for left side. In females, the mean right sphenoid sinus width was $(18.2 \pm 3.8) \mathrm{mm}$, and $(22.7 \pm 3.7) \mathrm{mm}$ for left side. Both sides in both genders showed statistical significant difference $(p \leq 0.05)$, as seen in Table 2 .

As cadaveric cases classified into age groups, the maximum width of sphenoid sinus for males belonged to group 1 on left side with $(20.4 \pm 4.4) \mathrm{mm}$ and the minimum width presented in group 4 on right side with $(14.4 \pm 3.2) \mathrm{mm}$. While for females the maxi- 
mum sinus width belonged to group 3 on left side with $(24.1 \pm 3.5) \mathrm{mm}$ and the minimum width presented in group 1 on right side with $(17.5 \pm 3.5) \mathrm{mm}$. For age grouping, ANOVA test was used. Although, the four groups on right side in males groups and left side in females reported a significant difference $(p \leq 0.05)$, but there was no significant difference recorded among the four groups of left side in males and right side in females ( $p>0.05)$, as shown in Table 3.

\section{Sphenoid sinus width measured by CT}

In males, the mean value for right sphenoid sinus width was $(19.6 \pm 4.1) \mathrm{mm}$, and for left sphenoid sinus was $(20.4 \pm 4.7) \mathrm{mm}$, whereas for females, the mean value of right sphenoid sinus width was $(17.3 \pm 5.2) \mathrm{mm}$ and for left side was $(19.2 \pm 5.6) \mathrm{mm}$. No significant side difference was recorded for both genders ( $p>0.05)$, as obvious in Table 4.

As cadaveric cases classified into age groups, the maximum width of the sphenoid sinus for males presented in group 3 on left side with $(21.4 \pm 4.4) \mathrm{mm}$, and the minimum width belonged to group 1 on right side with $(18.8 \pm 4.0) \mathrm{mm}$. On contrary for females, the maximum sinus width presented in group 2 on left side with $(22.1 \pm 5.4) \mathrm{mm}$, and the minimum width belonged to group 1 on right side with $(14.6 \pm 5.4) \mathrm{mm}$. When ANOVA test was applied, the difference in mean among the four age groups for both sides was statistically significant for females $(\mathrm{p} \leq 0.05)$ and not significant for males ( $p>0.05)$, as revealed in Table 5.

\section{Sphenoid sinus height measured in dissected human cadavers}

The mean value of right sphenoid sinus height for males was $(21.4 \pm 3.1) \mathrm{mm}$, and $(26.8 \pm 2.8) \mathrm{mm}$ of left side. In females, the mean value for right sphenoid sinus height was $(13.8 \pm 3.3) \mathrm{mm}$, and $(19.6 \pm 3.1) \mathrm{mm}$ for left side. Both sides in both genders showed a statistical significant difference $(\mathrm{p} \leq 0.05)$, as shown in Table 2.

As obvious in Table (3), in males of this study, the maximum height for sphenoid sinus presented in group 4 on left side with $(28.2 \pm 2.3) \mathrm{mm}$ and the minimum height presented in group 3 on right side with $(18.2 \pm 2.9) \mathrm{mm}$. While in females, the maximum height of it presented in group 2 on left side with $(22.4 \pm 3.3)$ $\mathrm{mm}$ and the minimum belonged to group 3 on right side with $(12.4 \pm 3.3) \mathrm{mm}$. When cadavers were grouped according to age, ANOVA test findings revealed significant statistical differences for both side's sinus height and in both genders among these four age groups $(p \leq 0.05)$.

\section{Sphenoid sinus height measured by CT}

In males, the mean value for right sphenoid sinus height was $(16.7 \pm 2.5) \mathrm{mm}$ and the mean value of left sphenoid sinus height was $(18.2 \pm 2.7) \mathrm{mm}$, whereas for females, the mean value for right sphenoid sinus height was $(14.6 \pm 2.9) \mathrm{mm}$ and the mean height for the left side was $(15.8 \pm 3.3) \mathrm{mm}$. No significant side difference was reported for both sides in both genders $(p>0.05)$ as summarized in Table 4.

In the present study, when cadaveric cases were classified into age groups, the maximum sinus height in males presented in group 1 on left side with $(19.6 \pm 2.8)$ $\mathrm{mm}$, and the minimum height belonged to group 2 on right side with $(15.4 \pm 2.7) \mathrm{mm}$. On contrary, for females, the maximum sinus height belonged to group 4 on left side with $(17.4 \pm 2.9) \mathrm{mm}$ and the minimum presented in group 3 on right side with $(12.4 \pm 3.0) \mathrm{mm}$. The differences in mean values among the four age groups in both genders of both sphenoid sinus heights were showed significant differences $(p \leq 0.05)$ when tested with ANOVA, as noted in Table 5.

Table 2. Sphenoid sinus measurements for both genders done by cadaveric dissection.

\begin{tabular}{|c|c|c|c|c|c|}
\hline & \multicolumn{2}{|c|}{ Male } & \multicolumn{2}{c|}{ Female } & \\
\cline { 2 - 6 } & Range & Mean \pm SD & Range & Mean \pm SD & P value \\
\hline $\begin{array}{c}\text { Right Sphenoid } \\
\text { sinus length } \\
\text { (mm) }\end{array}$ & $(6.4-40.8)$ & $24.8 \pm 4.2$ & $(8.4-37.3)$ & $24.5 \pm 3.7$ & $* \mathrm{p}>0.05$ \\
\hline $\begin{array}{c}\text { Left Sphenoid } \\
\text { sinus length } \\
\text { (mm) }\end{array}$ & $(13.1-43.2)$ & $23.6 \pm 3.8$ & $(10.7-38.6)$ & $25.3 \pm 4.1$ & $* \mathrm{p}>0.05$ \\
\hline $\begin{array}{c}\text { Right Sphenoid } \\
\text { sinus width } \\
\text { (mm) }\end{array}$ & $(6.5-38.1)$ & $15.8 \pm 3.2$ & $(8.3-34.7)$ & $18.2 \pm 3.8$ & $* * \mathrm{p} \leq 0.05$ \\
\hline $\begin{array}{c}\text { Left Sphenoid } \\
\text { sinus width } \\
\text { (mm) }\end{array}$ & $(10.2-40.2)$ & $19.2 \pm 4.5$ & $(5.6-37.4)$ & $22.7 \pm 3.7$ & $* * \mathrm{p} \leq 0.05$ \\
\hline $\begin{array}{c}\text { Right Sphenoid } \\
\text { sinus height } \\
\text { (mm) }\end{array}$ & $(4.1-30.2)$ & $21.4 \pm 3.1$ & $(2.1-25.4)$ & $13.8 \pm 3.3$ & $* * \mathrm{p} \leq 0.05$ \\
\hline $\begin{array}{c}\text { Left Sphenoid } \\
\text { sinus height } \\
\text { (mm) }\end{array}$ & $(6.4-42.3)$ & $26.8 \pm 2.8$ & $(9.8-46.1)$ & $19.6 \pm 3.1$ & $* * \mathrm{p} \leq 0.05$ \\
\hline
\end{tabular}

*p $>0.05=$ statistically not significant,

** $\mathrm{p} \leq 0.05$ = statistically significant 
Age Differences of Human Sphenoid Sinus Dimensions: a Comparative Study by Gross Anatomical Dissection

Table 3. Age difference groups for sphenoid sinus measurements for both genders done by cadaveric dissection

\begin{tabular}{|c|c|c|c|c|c|c|c|c|c|c|}
\hline & & \multicolumn{2}{|c|}{ Group 1} & \multicolumn{2}{|c|}{ Group 2} & \multicolumn{2}{|c|}{ Group 3} & \multicolumn{2}{|c|}{ Group 4} & \multirow{2}{*}{$P$ value } \\
\hline & & Range & Mean \pm SD & Range & Mean \pm SD & Range & Mean \pm SD & Range & Mean \pm SD & \\
\hline \multirow{6}{*}{$\frac{\frac{0}{\pi}}{\sum}$} & $\begin{array}{l}\text { Right Sphenoid sinus } \\
\text { length (mm) }\end{array}$ & $(9.3-36.6)$ & $22.7 \pm 4.6$ & $(6.4-39.2)$ & $26.7 \pm 3.8$ & $(11.6-40.5)$ & $26.3 \pm 4.5$ & $(13.2-40.8)$ & $23.5 \pm 3.9$ & $* * p \leq 0.05$ \\
\hline & $\begin{array}{l}\text { Left Sphenoid sinus } \\
\text { length }(\mathrm{mm})\end{array}$ & $(15.2-40.1)$ & $24.1 \pm 3.6$ & $(13.9-41.7)$ & $23.5 \pm 4.1$ & $(13.1-43.2)$ & $21.4 \pm 3.8$ & $(14.7-42.9)$ & $25.4 \pm 3.7$ & $* * p \leq 0.05$ \\
\hline & $\begin{array}{l}\text { Right Sphenoid sinus } \\
\text { width }(\mathrm{mm})\end{array}$ & $(9.0-36.4)$ & $15.2 \pm 3.8$ & $(12.2-35.5)$ & $17.3 \pm 2.8$ & $(10.4-38.1)$ & $16.3 \pm 3.0$ & $(6.5-37.2)$ & $14.4 \pm 3.2$ & $* * p \leq 0.05$ \\
\hline & $\begin{array}{l}\text { Left Sphenoid sinus } \\
\text { width (mm) }\end{array}$ & $(13.1-38.4)$ & $20.4 \pm 4.4$ & $(10.2-37.1)$ & $18.2 \pm 4.7$ & $(12.2-39.3)$ & $19.6 \pm 4.8$ & $(14.5-40.2)$ & $18.6 \pm 4.1$ & ${ }^{*} p>0.05$ \\
\hline & $\begin{array}{l}\text { Right Sphenoid sinus } \\
\text { height (mm) }\end{array}$ & $(4.1-28.7)$ & $22.3 \pm 3.6$ & $(7.2-30.2)$ & $20.8 \pm 3.3$ & $(9.3-27.6)$ & $18.2 \pm 2.9$ & $(8.4-29.7)$ & $24.3 \pm 2.6$ & $* * p \leq 0.05$ \\
\hline & $\begin{array}{l}\text { Left Sphenoid sinus } \\
\text { height }(\mathrm{mm})\end{array}$ & $(10.6-39.6)$ & $27.5 \pm 2.6$ & $(9.2-42.3)$ & $24.8 \pm 3.1$ & $(8.7-40.5)$ & $26.7 \pm 3.2$ & $(6.4-41.8)$ & $28.2 \pm 2.3$ & $* * p \leq 0.05$ \\
\hline \multirow{6}{*}{ 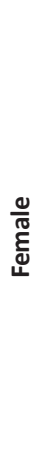 } & $\begin{array}{l}\text { Right Sphenoid sinus } \\
\text { length (mm) }\end{array}$ & $(8.4-35.5)$ & $23.6 \pm 4.1$ & $(8.8-34.6)$ & $26.1 \pm 3.8$ & $(10.2-36.1)$ & $24.5 \pm 3.8$ & $(10.6-37.3)$ & $23.8 \pm 3.1$ & ${ }^{*} p>0.05$ \\
\hline & $\begin{array}{l}\text { Left Sphenoid sinus } \\
\text { length }(\mathrm{mm})\end{array}$ & $(11.3-36.7)$ & $26.2 \pm 3.8$ & $(10.7-35.4)$ & $25.1 \pm 4.2$ & $(12.4-38.6)$ & $27.6 \pm 4.1$ & $(13.5-38.1)$ & $22.3 \pm 4.3$ & $* * p \leq 0.05$ \\
\hline & $\begin{array}{l}\text { Right Sphenoid sinus } \\
\text { width }(\mathrm{mm})\end{array}$ & $(8.3-29.8)$ & $17.5 \pm 3.5$ & $(12.1-34.7)$ & $18.2 \pm 3.4$ & $(11.7-31.9)$ & $19.5 \pm 4.4$ & $(11.3-30.7)$ & $17.6 \pm 3.9$ & $* p>0.05$ \\
\hline & $\begin{array}{l}\text { Left Sphenoid sinus } \\
\text { width }(\mathrm{mm})\end{array}$ & $(5.6-30.2)$ & $23.1 \pm 4.1$ & $(11.7-33.4)$ & $20.3 \pm 4.0$ & $(9.3-37.4)$ & $24.1 \pm 3.5$ & $(7.8-36.2)$ & $23.3 \pm 3.2$ & $* * p \leq 0.05$ \\
\hline & $\begin{array}{l}\text { Right Sphenoid sinus } \\
\text { height (mm) }\end{array}$ & $(3.4-21.8)$ & $12.6 \pm 2.9$ & $(6.7-23.7)$ & $16.1 \pm 2.8$ & $(2.1-25.4)$ & $12.4 \pm 3.3$ & $(5.4-24.8)$ & $14.1 \pm 4.2$ & $* * p \leq 0.05$ \\
\hline & $\begin{array}{l}\text { Left Sphenoid sinus } \\
\text { height }(\mathrm{mm})\end{array}$ & $(9.8-44.6)$ & $20.1 \pm 3.2$ & $(11.1-46.1)$ & $22.4 \pm 3.3$ & $(12.4-43.9)$ & $17.3 \pm 3.6$ & $(12.6-45.4)$ & $18.6 \pm 2.3$ & $* * p \leq 0.05$ \\
\hline
\end{tabular}

*p $>0.05=$ statistically not significant,$\quad{ }^{* *} \mathrm{p} \leq 0.05=$ statistically significant

Table 4. Sphenoid sinus measurements for both genders done by $\mathrm{CT}$ scan

\begin{tabular}{|c|c|c|c|c|c|}
\hline & \multicolumn{2}{|c|}{ Male } & \multicolumn{2}{|c|}{ Female } & \multirow[b]{2}{*}{ P value } \\
\hline & Range & Mean \pm SD & Range & Mean \pm SD & \\
\hline Right Sphenoid sinus length ( $\mathrm{mm}$ ) & $(8.3-42.1)$ & $25.4 \pm 3.1$ & $(9.1-36.2)$ & $21.3 \pm 4.2$ & $* * p \leq 0.05$ \\
\hline Left Sphenoid sinus length (mm) & $(12.6-50.2)$ & $27.2 \pm 4.1$ & $(11.3-43.1)$ & $24.4 \pm 3.8$ & $* p>0.05$ \\
\hline Right Sphenoid sinus width (mm) & $(7.4-37.4)$ & $19.6 \pm 4.1$ & $(7.1-34.7)$ & $17.3 \pm 5.2$ & $* p>0.05$ \\
\hline Left Sphenoid sinus width (mm) & $(13.6-41.2)$ & $20.4 \pm 4.7$ & $(12.5-36.1)$ & $19.2 \pm 5.6$ & $* p>0.05$ \\
\hline Right Sphenoid sinus height (mm) & $(2.9-25.1)$ & $16.7 \pm 2.5$ & $(1.8-24.2)$ & $14.6 \pm 2.9$ & $* p>0.05$ \\
\hline Left Sphenoid sinus height (mm) & $(3.5-28.4)$ & $18.2 \pm 2.7$ & $(2.7-26.2)$ & $15.8 \pm 3.3$ & ${ }^{*} \mathrm{p}>0.05$ \\
\hline
\end{tabular}

$* \mathrm{p}>0.05=$ statistically not significant,$\quad * * \mathrm{p} \leq 0.05=$ statistically significant 
Table 5. Age difference groups for sphenoid sinus measurements for both genders done by CT scan

\begin{tabular}{|c|c|c|c|c|c|c|c|c|c|c|}
\hline & & \multicolumn{2}{|c|}{ Group 1} & \multicolumn{2}{|c|}{ Group 2} & \multicolumn{2}{|c|}{ Group 3} & \multicolumn{2}{|c|}{ Group 4} & \multirow[b]{2}{*}{$P$ value } \\
\hline & & Range & Mean \pm SD & Range & $\begin{array}{l}\text { Mean } \pm \\
\text { SD }\end{array}$ & Range & $\begin{array}{l}\text { Mean } \pm \\
\text { SD }\end{array}$ & Range & Mean \pm SD & \\
\hline \multirow{6}{*}{$\frac{0}{\frac{0}{\pi}}$} & \begin{tabular}{|c|}
$\begin{array}{c}\text { Right Sphenoid sinus } \\
\text { length }(\mathrm{mm})\end{array}$ \\
\end{tabular} & $(8.3-42.1)$ & $26.6 \pm 3.6$ & $\begin{array}{l}(10.2- \\
40.3)\end{array}$ & $26.1 \pm 3.2$ & $(9.4-39.5)$ & $23.6 \pm 2.9$ & $(9.1-41.6)$ & $25.3 \pm 3.0$ & $* * p \leq 0.05$ \\
\hline & $\begin{array}{l}\text { Left Sphenoid sinus } \\
\text { length }(\mathrm{mm})\end{array}$ & $\begin{array}{l}(15.1- \\
50.2)\end{array}$ & $29.1 \pm 4.2$ & $\begin{array}{l}(12.6- \\
48.5)\end{array}$ & $27.7 \pm 4.0$ & $\begin{array}{l}(14.1- \\
47.5)\end{array}$ & $24.5 \pm 3.8$ & $\begin{array}{l}(17.2- \\
50.0)\end{array}$ & $27.5 \pm 4.3$ & $* * p \leq 0.05$ \\
\hline & $\begin{array}{c}\text { Right Sphenoid sinus } \\
\text { width (mm) }\end{array}$ & $(9.2-36.3)$ & $18.8 \pm 4.0$ & $(9.6-34.6)$ & $20.1 \pm 3.6$ & $(7.4-34.4)$ & $19.1 \pm 4.0$ & $(8.1-37.4)$ & $20.4 \pm 3.7$ & $* p>0.05$ \\
\hline & $\begin{array}{l}\text { Left Sphenoid sinus } \\
\text { width (mm) }\end{array}$ & $\begin{array}{l}(14.2- \\
39.6)\end{array}$ & $20.0 \pm 5.1$ & $\begin{array}{l}(13.6- \\
38.5)\end{array}$ & $19.6 \pm 4.3$ & $\begin{array}{l}(15.6- \\
38.1)\end{array}$ & $21.4 \pm 4.4$ & $\begin{array}{l}(16.1- \\
41.2)\end{array}$ & $20.6 \pm 4.6$ & $* p>0.05$ \\
\hline & $\begin{array}{c}\text { Right Sphenoid sinus } \\
\text { height }(\mathrm{mm})\end{array}$ & $(3.5-25.1)$ & $18.1 \pm 3.1$ & $(4.1-23.8)$ & $15.4 \pm 2.7$ & $(2.9-22.7)$ & $15.7 \pm 3.1$ & $(5.1-24.6)$ & $17.6 \pm 2.8$ & $* * p \leq 0.05$ \\
\hline & $\begin{array}{l}\text { Left Sphenoid sinus } \\
\text { height (mm) }\end{array}$ & $(4.6-28.4)$ & $19.6 \pm 2.8$ & $(3.5-27.1)$ & $18.6 \pm 3.0$ & $(5.1-25.4)$ & $17.7 \pm 2.5$ & $(6.2-26.2)$ & $16.9 \pm 3.2$ & $* * p \leq 0.05$ \\
\hline \multirow{6}{*}{$\begin{array}{l}\frac{0}{\frac{0}{\sigma}} \\
\text { हैँ } \\
\text { एँ }\end{array}$} & \begin{tabular}{|c|}
$\begin{array}{c}\text { Right Sphenoid sinus } \\
\text { length }(\mathrm{mm})\end{array}$ \\
\end{tabular} & $\begin{array}{l}(12.4- \\
33.3)\end{array}$ & $21.0 \pm 4.1$ & $(9.1-35.5)$ & $23.1 \pm 4.3$ & $\begin{array}{l}(13.0- \\
35.1)\end{array}$ & $18.6 \pm 3.8$ & $\begin{array}{l}(10.6- \\
36.2)\end{array}$ & $22.5 \pm 4.2$ & $* * p \leq 0.05$ \\
\hline & $\begin{array}{l}\text { Left Sphenoid sinus } \\
\text { length (mm) }\end{array}$ & $\begin{array}{l}(11.3- \\
39.8)\end{array}$ & $25.6 \pm 3.7$ & $\begin{array}{l}(13.2- \\
42.1)\end{array}$ & $24.1 \pm 4.4$ & $\begin{array}{l}(12.1- \\
40.6)\end{array}$ & $26.2 \pm 4.2$ & $\begin{array}{c}(11.7- \\
43.1)\end{array}$ & $21.7 \pm 3.6$ & $* * p \leq 0.05$ \\
\hline & $\begin{array}{c}\text { Right Sphenoid sinus } \\
\text { width }(\mathrm{mm})\end{array}$ & $(9.1-29.7)$ & $14.6 \pm 5.4$ & $(8.2-34.7)$ & $19.4 \pm 5.2$ & $\begin{array}{l}(10.4- \\
30.5)\end{array}$ & $17.6 \pm 4.8$ & $(7.1-31.2)$ & $17.6 \pm 4.6$ & $* * p \leq 0.05$ \\
\hline & $\begin{array}{l}\text { Left Sphenoid sinus } \\
\text { width (mm) }\end{array}$ & $\begin{array}{l}(12.5- \\
34.9)\end{array}$ & $20.1 \pm 5.2$ & $\begin{array}{l}(15.1- \\
36.1)\end{array}$ & $22.1 \pm 5.4$ & $\begin{array}{l}(14.2- \\
34.8)\end{array}$ & $16.0 \pm 4.3$ & $\begin{array}{l}(13.1- \\
35.2)\end{array}$ & $18.6 \pm 4.8$ & $* * p \leq 0.05$ \\
\hline & $\begin{array}{c}\text { Right Sphenoid sinus } \\
\text { height }(\mathrm{mm})\end{array}$ & $(2.6-22.3)$ & $13.6 \pm 3.1$ & $(3.1-24.2)$ & $16.2 \pm 2.8$ & $(4.7-20.6)$ & $12.4 \pm 3.0$ & $(1.8-21.8)$ & $16.2 \pm 2.5$ & $* * p \leq 0.05$ \\
\hline & $\begin{array}{l}\text { Left Sphenoid sinus } \\
\text { height (mm) }\end{array}$ & $(3.4-26.2)$ & $16.1 \pm 3.4$ & $(5.2-22.7)$ & $14.5 \pm 3.1$ & $(2.7-25.4)$ & $15.2 \pm 2.8$ & $(4.1-24.6)$ & $17.4 \pm 2.9$ & $* * p \leq 0.05$ \\
\hline
\end{tabular}

*p $>0.05=$ statistically not significant,$\quad{ }^{* *} \mathrm{p} \leq 0.05=$ statistically significant

\section{DISCUSSION}

The dimensions of the sphenoid sinus in the cadaveric cases of this study was in agreement in its length and width, but not the height, to a study done by Stoković et al ${ }^{16}$ who stated that the dimensions of this sinus were $(23 \times 20 \times 17) \mathrm{mm}$, and the cause may be due to ethnic variations.

Idowu et al ${ }^{17}$ who carried out a study on sixty adult Nigerians with a high-resolution spiral CT scan found that the mean value of right sphenoid sinus length was $23.8 \mathrm{~mm}$ and the left was $26.0 \mathrm{~mm}$, while the right sphenoid sinus width was $18.6 \mathrm{~mm}$ and the left was $20.1 \mathrm{~mm}$. Therefore, there was a very close relationship with the results of the current study in the length and width, which may be due to the similarity in the device and techniques used in the two studies.

A radiological study done by Barghouth et al ${ }^{18}$ demonstrated that the mean values for sphenoid sinus length, width, and height were (23.0 \pm 4.5$),(12.8 \pm 3.1)$,
(22.6 \pm 5.8$) \mathrm{mm}$ respectively. In comparison to their corresponding findings of the present study, one can see the disagreement in the width and height with the current study, which might explain due to the technique used in Barghouth et al ${ }^{18}$ study, which was the MRI since it is less evidence in determining the bony structures.

Group 1 of sphenoid sinus in the present study, reported with the highest values among other aging groups in three parameters; length for left sinus in male CT cases, width for left sphenoid sinus in male anatomical cases and height of left sinus in male CT cases. In contrast to that, group 1 reported the lowest values among other aging groups in three parameters; width for right sinus in male CT cases, width for right sinus in a female of both anatomical and CT cases. The last three findings of this study might reflect that in group 1 , the growth in the width of the sphenoid sinus is less than that in its length and height.

Concerning group 2 of sphenoid sinus in current study, this appeared with the highest values among other aging groups in three parameters that including; 
length for right sinus in male anatomical cases, width for left sinus in female CT cases, and height for left sinus in female anatomical cases. Whereas, group 2 was found as the lowest values among other aging groups in just one parameter, which was the height for right sinus of male CT cases. So that from those findings, group 2 might show mild progress in sphenoid sinus growth in its three dimensions.

Regarding group 3 of sphenoid sinus of the present study, this group revealed the highest values among other aging groups in four parameters which including; length for left sinus in females of both anatomical and CT cases, width for left sinus of male CT cases, and width for left sinus in female anatomical cases. While, group 3 presented with the lowest values among other aging groups in six parameters; length for left sinus of male anatomical cases, length for right sinus of CT cases of both genders, height for right sinus of female CT cases, and height for right sinus of anatomical cases in both genders. Reading to these findings, group 3 of sphenoid sinus might show remarkable growth in its length and width on the left side, in association with decreasing growth in its length and height on the right side, without any obvious related anatomical explanation for these growth changes.

Group 4 of sphenoid sinus of the present study noted the highest values among other aging groups in only two parameters; height for left sinus of male anatomical cases and height for left sinus of female CT cases. On contrary, group 4 showed the lowest values among other aging groups in another two parameters; length for left sinus of female anatomical cases, width for right sinus of male anatomical cases. From all these four findings, but mostly due to the first two findings, group 4 could be partly revealing that the sphenoid sinus reaches its full height if it early fails to get it at group 3 .

Despite the long and deep searching, most of the previous studies did not mention the sphenoid sinus dimensions according to age groups, only based on measurements of the sinus volume. Hasan et $\mathrm{al}^{19}$ determined the volume of this sinus in about 105 skulls by using melted wax and the findings of their study were 3.01, 2.31, and $5.3 \mathrm{cc}$ for the right, left and both sides respectively. Karakas et al ${ }^{20}$ performed a CT scans study on 91 (44 females and 47 males) classified into the following age groups (5-10), (11-15), (16-20), (21-25), and $(>25)$ years old. Firstly, they recorded the mean sinus volume $6.00 \pm 3.02 \mathrm{cc}$ in females, $6.83- \pm 3.73 \mathrm{cc}$ in males, and $6.43 \pm 3.41 \mathrm{cc}$ in all individuals. Secondly, the sphenoid sinus volume in males was $2.96 \pm 2.53$, $5.40 \pm 1.96,7.50 \pm 3.21,9.68 \pm 2.62$ and $8.53 \pm 4.19$ cc respectively; but in females was $3.14 \pm 2.30,4.85 \pm 1.09$, $5.43 \pm 2.59,8.71 \pm 2.44$ and $7.88 \pm 2.99$ cc respectively for the same previous age groups. The above findings disagreed with the findings of the present study (if the volume was mathematically calculated). In addition, Oliveira et $\mathrm{al}^{21}$ performed a study on fifty patients $(25$ males and 25 females) without any age indication; they measured the sinus volume according to gender only. They recorded the mean volume in males was $15.4 \mathrm{cc}$, in females was $10.88 \mathrm{cc}$ and in overall cases was 13.14 cc; which also disagreed with present study findings.

\section{CONCLUSIONS}

The findings from CT scanning technology when correlated with findings based on gross cadaveric dissections yield accurate living anatomic views for sphenoid sinus, which were better and more satisfactorily than classic anatomical sections. Therefore, the findings from both methods could provide valuable and precise measurements that cannot be approached by other means. These findings may play great importance in expectation for gender, age, and race in order to determine alive or even dead individuals' identity.

Compliance with ethics requirements: The authors declare no conflict of interest regarding this article. The authors declare that all the procedures and experiments of this study respect the ethical standards in the Helsinki Declaration of 1975, as revised in 2008(5), as well as the national law. Informed consent was obtained from all the patients included in the study. 


\section{References}

1. Berkovitz B, Bernard JM. Head and neck anatomy a clinical reference. 14 edition. London: Martin Dunitz Ltd; 2016:188-243.

2. Akgül $M H$, Muluk NB, Burulday $\mathrm{V}$, Kaya A. Is there a relationship between sphenoid sinus types, septation and symmetry; and septal deviation? Eur Arch Otorhinolaryngol. 2016 Dec;273(12):4321-4328. DOI: 10.1007/s00405-016-4138-7.

3. Doubi A, Albathi A, Sukyte-Raube D, Castelnuovo P, Alfawwaz F, AlQahtani A. Location of the Sphenoid Sinus Ostium in Relation to Adjacent Anatomical Landmarks. Ear Nose Throat J. 2020 Jun;8:145561320927907.

4. Abdalla MA. Pneumatization patterns of human sphenoid sinus associated with the internal carotid artery and optic nerve by CT scan. Ro J Neurol. 2020:19(4);244-251. DOI: 10.37897/ RJN.2020.4.5

5. Seeram E. Computed tomography technology. $4^{\text {th }}$ ed. PhiladeIphia: WB Saunders Company; 2016:147-167.

6. Pirinc B, Fazliogullari Z, Guler I, Dogan N, Uysal I, Karabulut $A$. Classification and volumetric study of the sphenoid sinus on MDCT images. Eur Arch Otorhinolaryngol. 2019;276:28872894. DOI: 10.1007/s00405-019-05549-8

7. Abdalla M A. Maxillary Sinus Dimensions of Different Human Age Groups by CT Scan Imaging. Medicina Moderna. 2021;28(2):235-241. DOI: 10.31689/rmm.2021.28.2.235

8. Turkdogan FT, Turkdogan KA, Dogan M, Atalar MH. Assessment of sphenoid sinus related anatomic variations with computed tomography. Pan African Medical Journal. 2017;27:109. DOI: 10.11604/pamj.2017.27.109.7391

9. Kumar B S, Selvi G P. Morphometry of sphenoid air sinus and its ostium for surgical relevance: A cadaveric study. J Anat Soc India 2020;69:133-136. DOI: 10.4103/JASI.JASI_110_19

10. Abdalla M A. Age Differences of Human Frontal Sinus Measurements using CT Scan. J Adv Med Biomed Res. 2021;29(136):293301. DOI: 10.30699/jambs.29.136.293

11. Balegh AH, Moustafa T. Anatomical Variations of Paranasal Sinuses on Multidetector Computed Tomography. On J Otolaryngol Rhinol. 2020;3(2):556. DOI: 10.33552/OJOR.2020.03.000556

12. Mohammad SA, Abdalla MA, Mahdi AJJ. Orbitometry of orbital opening and orbital cavity in neonate compared adult. Tik Med J. 2011;210-216.
13. Cohen O, Warman M, Fried M, Shoffel-Havakuk H, Adi M, Halperin $\mathrm{D}$, et al. Volumetric analysis of the maxillary, sphenoid and frontal sinuses: a comparative computerized tomography based study. Auris Nasus Larynx. 2018;45(1):96-102. DOI: 10.1016/j. anl.2017.03.003 PMID: 28341352

14. Abdalla MA, Mahdi AJJ. Maxillary Sinus Measurements in Different Age Groups of Human Cadavers. Tik J Dent Sci. 2013;1:107-112.

15. Yalcin ED. Assessment of sphenoid sinus types in patients with cleft lip and palate on cone-beam CT. Eur Arch Otorhinolaryngol. 2020 Apr;277(4):1101-1108. DOI: 10.1007/s00405-02005810-5

16. Štoković N, Trkulja V, Dumić-Čule I, Čuković-Bagić I, Lauc T, Vukičević $\mathrm{S}$, et al. Sphenoid sinus types, dimensions and relationship with surrounding structures. Ann Anat 2016;203:69-76. DOI: 10.1016/j.aanat.2015.02.013

17. Idowu OE, Balogun BO, Okoli CA. Dimensions, septation, and pattern of pneumatization of the sphenoidal sinus. Folia Morphol (Warsz). 2009;68:228-232.

18. Barghouth G, Prior JO, Lepori D, Duvoisin B, Schnyder P, Gudinchet $F$. Paranasal sinuses in children: size evaluation of maxillary, sphenoid and frontal sinuses by magnetic resonance imaging and proposal of volume index percentile curves. Eur Radiol J. 2002 Jun;12(6):1451-1458. DOI: 10.1007/s00330001-1218-9

19. Hasan SA, Faruqi NA. A morphometric study of the sphenoidal sinus. Indian J Otolaryngol. 1984;36:23-25. DOI: 10.1007/ BF02994150

20. Karakas S, Kavakli A. Morphometric examination of the paranasal sinuses and mastoid air cells using computed tomography. Ann Saudi Med. 2005;25:41-45. DOI: 10.5144/02564947.2005.41

21. Oliveira JM, Alonso MB, de Sousa E Tucunduva MJ, Fuziy A, Scocate AC, Costa AL. Volumetric study of sphenoid sinuses: anatomical analysis in helical computed tomography. Surg Radiol Anat. 2017 Apr;39(4):367-374. DOI: 10.1007/s00276-0161743-5 